Vol. 8 (9), pp. 251-256, 2018

ISSN: 2276-7770; ICV: 6.15

Copyright $@ 2018$, the copyright of this article is retained by the author(s)

DOI Link: http://doi.org/10.15580/GJAS.2018.9.091218135

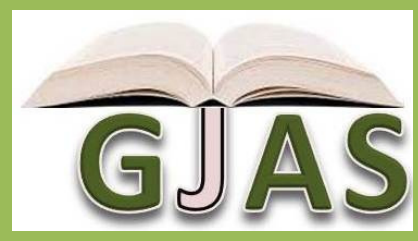

http://gjournals.org/GJAS

\title{
Assessment of use of Information and Communication Technologies (ICTs) by Farmers in Makurdi Local Government of Benue State: Implications for Accessing Marketing Information
}

\author{
OTENE, V. A., IJUH, R. H., IHEANAETU, A. C. and CHIA, J. I.
}

Department of Agricultural Extension and Communication, University of Agriculture Makurdi.

\section{ARTICLE INFO}

Article No.: 091218135

Type: Research

DOI: 10.15580/GJAS.2018.9.091218135

Submitted: 12/09/2018

Accepted: 19/09/2018

Published: 29/09/2018

*Corresponding Author

Victor Otene

E-mail: otlevite@yahoo.com

\section{ABSTRACT}

This study was carried out to assess the use of ICTs by farmers in Makurdi Local Government Area of Benue State, Nigeria, with a view of the ICTs being used to obtain marketing information. Farmers in Makurdi form the population of the study, and were selected using purposive and random sampling techniques. Primary data were used, collected using a structured questionnaire. The data were analyzed using descriptive and inferential statistics. Research findings revealed that the average age of the respondents was 37.2 years, $89.2 \%$ had formal education, and the mean farming experience was 16.5 years. The mean household size was 16.5 persons, mean farm size was $3.74 \mathrm{Ha}$, while the mean income was N451, 226.7. The highly accessed ICTs were mobile phone $(\bar{x}=2.65)$ and television $(\bar{x}=2.49)$. Mobile phone and television were also mostly used by the respondents. Farming experience $(W=-2.47)$ and farm size $(W=1.99)$ significantly affected the respondents' level of ICT use. It was therefore recommended that marketing information be conveyed to the respondents through the highly accessed and used ICTs, while they are encouraged to use the other ICTs.

Keywords:

Assessment, Information and

Communication Technologies,

Implications, Marketing information 


\section{INTRODUCTION}

Agriculture is one of the most important sectors of the Nigeria economy. It contributes more than $30 \%$ of the gross domestic product (GDP), employs about $70 \%$ of the labour force, accounts for over $70 \%$ of the non-oil export, and perhaps most importantly, provides over $80 \%$ of the food needs of the country (Adegboye, 2004).

Agricultural marketing covers the services involved in moving an agricultural product from the farm to the consumer. It is also the planning, organization, directing and handling of agricultural produce in such a way as to satisfy the farmer, producer and the consumer. Efficient market information can be shown to have positive benefits for farmers, and traders' up to date information on price and other factors enables farmers to negotiate with traders and also facilitates spatial distribution of products from rural areas to towns and between markets (Ajayi, 2002).

Farmers frequently consider marketing as being their major problem (Hassan et al., 2009). Losses occurring from lack of marketing access can range from damaging of produce as a result of extreme temperature exposure, disease infestation and middlemen exploitation. Markets play a crucial role in agriculture, as the livelihoods of the majority of world's poor people depend on participating in markets either as workers or producer with many successes in poverty reduction historically being associated with the growth of market and private economy (FAO, 2009).

Information and Communication Technology (ICT) is an umbrella term that includes any communication devices or application, encompassing radio, television, cellular phones, computer and network hardware and software, satellite system and soon, as well as the various services and applications associated with them such as video conferences and distance learning (Molony, 2008). It also encompasses diverse set of technological tools and resources used to communicate, and to create, disseminate, store and manage information. These technologies include computers, the internet, broadcasting technologies and telephony. These technologies, if applied could ease the process of agricultural marketing.

Benue State is the agricultural hub of Nigeria, and is referred to as the food basket of the Nation. With the heightened agricultural activities in the State, the farmers would need information to market their produce profitably. It is therefore necessary to find out if the farmers have access to, and use ICTs to access information. This knowledge would provide a foundation, if ICTs can be used to communicate marketing information to the farmers. This forms the basis of this research, with the following specific objectives:

i. describe the socio-economic characteristics of rural farmers in the study areas; ii. determine the level of access to ICTs among rural farmers in the study area; and

iii. determine the level of usage of ICTs among rural farmers in Makurdi Local Government;

The following hypothesis was stated and tested:

Socio-economic characteristics of rural farmers have no significant effect on their level of usage of information and communication technologies (ICTs).

\section{MATERIALS AND METHODS}

\section{The Study Area}

The area of study is Makurdi Local Government of Benue State, Nigeria. Makurdi is the capital of Benue State. It was established in the early twenties and gained prominence in 1927 when it became the headquarters of the then Benue province. Makurdi became the capital of Benue State in 1976 (BNARDA, 2005). It lies between longitude $8^{\circ}$ and $9^{\circ} \mathrm{E}$ and latitude $7^{\circ}$ and $8^{\circ} \mathrm{N}$. The Local Government shares boundaries with Guma to the North, Gwer to the South, Tarka to the East and to the West by Gwer West Local Government Area. An essential feature of this area is River Benue which divides the Local Government into two namely Northern part called North Bank and the Southern part called South Bank. It has a population of $3,003,077$ (NPC, 2006) and occupies a landmass of 30,955 square kilometers (BNARDA, 2005).

Farming is the major occupation of the people with about $75 \%$ of the population engage in farming activities which is mostly subsistence in nature (Okwu et al., 2007)). Other occupations such as fishing, civil services, artisans and marketing are also important. There are eleven (11) council wards in Makurdi.

\section{Method of Data Collection}

Primary data were used for the study, and were collected using a structured questionnaire consisting of four sections, A to $\mathrm{C}$. Section A covered information on the socio-economic characteristics of the respondents, section $B$ covered information on the level of access to ICTs, while section $\mathrm{C}$ contained information on the level of usage of ICTs.

\section{Sampling Procedure and Sample Size}

The population for this study comprised the farmers in Makurdi Local Government Area. Six (6) council wards were purposively selected from the 11 council wards of the Local Government. The six were selected due to high availability of ICTs and rich agricultural production. The selected council wards are Agan, Kanshio, Fildi, North Bank, Bar, Modern Market. 
In the second stage, two settlements from each of the selected council wards were randomly selected. A reconnaissance survey puts the number of farmers in the selected council wards as 2393 and a proportional allocation of $5 \%$ of the sampling frame was selected to obtain a sample size of 120 respondents.

\section{Measurement of Variables}

The dependent variable, level of use of ICTs was measured using a Likert scale ranging from low to high. Respondents with low or medium level of use are considered as having low level of use, while those that indicated high are considered as having high level of use of ICTs.

\section{Independent Variables}

1. Age: This was measured by indicating the respondent's chronological age in years.

2. Education: This was measured as dummy variable, $1=$ formal education, $0=$ no formal education.

3. Farming experience: this was measured as the number of years spent in agricultural activities.

4. Household size: this is the number of people living in the house of the respondent at the time of data collection.

5. Farm size: this is the size of farmland cultivated by the respondents, measured in hectares.

6. Income: this is the money that the respondents obtain from their farming activities in Naira.

\section{Methods of Data Analysis}

Descriptive and inferential statistics were used to analyze the collected data. Descriptive statistics such as percentages, mean and Likert scales were used achieve the objectives, while binary logistic regression was used to test the hypothesis.

\section{RESULTS AND DISCUSSION}

\section{Socio-economic Characteristics of Respondents}

The findings on the socio-economic characteristics of the respondents is presented in Table 1. It was found that majority of the respondents $(32.5 \%)$ were within the ages of 31 and 40 years. This indicates that most of the respondents were adults and falls within the economically active age group as defined Food and Agriculture Organization (FAO) (2009), and are more likely to use ICTs facilities considering their active age range.

Most of the respondents $(89.16 \%)$ had a formal education and only $10.83 \%$ had no formal education. This implies that the respondents were knowledgeable enough to operate their ICTs and can obtain agricultural information through these ICTs facilities. This finding is similar to that of Otene et al. (2017)

With respect to farming experience, $30 \%$ of the respondents had farming experience between 5 and 9 years, while $26.67 \%$ of them had experience of more than 20 years. From the analysis, the average farming experience is 16.5 years, implying that the farmers in the study area are experienced. This could hinder the uptake of use of ICTs, as they may depend on their previous experiences to market their produce.

Research findings reveal that majority (53.33) of the respondents had a household size of 5-9 persons. A large household size would facilitate the flow of information from one person to another. This further implies that the respondents are prone to cheap labor provided by family members and are more likely to have information on market access from members of their family. It also increases the likelihood of members of the family to have access to ICTs.

Most of the respondents $(65.83 \%)$ had a farm size that is less or equal to 3 ha. This implies that the respondents are small scale farmers. They will therefore, need agricultural information to obtain optimum output from their small farms and market their farm produce efficiently. These findings are similar to that of Afloabi (2010) and Otene et al. (2017).

Research findings revealed that majority of the respondents (38.33\%) earned between $\mathrm{N} 250,000$ and $\mathrm{N}$ 500,000 . This indicates that the farmers do not earn much from their farms and further buttresses the assertion that they are small-scale farmer's spending money on ICTs facilities could be a challenge to the lowincome earning farmers. 
Table 1: Socio - economic Characteristics of Respondents $(n=120)$

\begin{tabular}{|c|c|c|c|}
\hline $\begin{array}{l}\text { Socio economic } \\
\text { characteristics }\end{array}$ & Frequency & Percentage (\%) & Mean $(\bar{x})$ \\
\hline \multicolumn{4}{|l|}{ Age (Years) } \\
\hline$\leq 20$ & 3 & 2.50 & \\
\hline $21-30$ & 38 & 31.6 & \\
\hline $31-40$ & 39 & 32.5 & \\
\hline $41-50$ & 25 & 20.8 & \\
\hline $51-60$ & 10 & 8.3 & \\
\hline$>60$ & 5 & 4.1 & 37.2 \\
\hline \multicolumn{4}{|l|}{ Level of education } \\
\hline Formal education & 107 & 89.2 & \\
\hline No formal education & 13 & 10.8 & \\
\hline \multicolumn{4}{|c|}{ Farming experience (Years) } \\
\hline$\leq 4$ & 12 & 10.0 & \\
\hline $5-9$ & 36 & 30.0 & \\
\hline $10-14$ & 24 & 20.0 & \\
\hline $15-19$ & 16 & 13.3 & \\
\hline$\geq 20$ & 32 & 26.6 & 16.5 \\
\hline \multicolumn{4}{|c|}{ Household size (Persons) } \\
\hline$\leq 4$ & 12 & 10.0 & \\
\hline $5-9$ & 36 & 30.0 & \\
\hline $10-14$ & 24 & 20.0 & \\
\hline $15-19$ & 16 & 13.3 & \\
\hline$\geq 20$ & 32 & 26.6 & 7.0 \\
\hline Farm size (Ha) & 79 & 65.5 & \\
\hline $0-3$ & 79 & 65.5 & \\
\hline $3.1-5.0$ & 21 & 17.5 & \\
\hline $5.1-7.0$ & 7 & 5.5 & \\
\hline$>7$ & 13 & 10.5 & 3.74 \\
\hline \multicolumn{4}{|l|}{ Income (N) } \\
\hline$\leq 250,000$ & 41 & 34.1 & \\
\hline $250,001-500,000$ & 46 & 38.3 & \\
\hline $500,001-750,000$ & 14 & 11.6 & \\
\hline $750,001-1,000,000$ & 10 & 8.3 & \\
\hline$>1,000,000$ & 9 & 7.5 & $451,266.7$ \\
\hline
\end{tabular}

\section{Accessibility of Respondents to ICTs}

The analysis on level of access to ICTs is presented in Table 2. Research findings revealed that majority $(73.33 \%)$ of the respondents had a high accessibility to mobile phones. The result showed that $60.0 \%$ of the respondents had access to television. Since most of them had mobile phone and television, these are good channels through which marketing information could be communicated with the farmers. This agrees with the findings of Pade et al. (2005) which noted that currently, cellular phone has become a popular device for communication particularly because of the ease of deployment of technology, the low cost associated with acquisition of mobile device, which made them ubiquitous. 
Table 2: Farmers' Accessibility to ICTs

\begin{tabular}{|c|c|c|c|c|c|c|c|}
\hline \multirow[t]{3}{*}{ ICTs } & \multicolumn{6}{|c|}{ LEVEL OF ACCESS } & \multirow[t]{3}{*}{ Mean $(\bar{x})$} \\
\hline & \multicolumn{2}{|c|}{ Low } & \multicolumn{2}{|c|}{ Medium } & \multicolumn{2}{|c|}{ High } & \\
\hline & Freq. & $\%$ & Freq. & $\%$ & Freq. & $\%$ & \\
\hline Television & 9 & 7.5 & 37 & 30.8 & 72 & 60.0 & 2.49 \\
\hline Internet & 34 & 28.3 & 30 & 25.0 & 19 & 15.8 & 1.25 \\
\hline Mobile phone & 5 & 4.17 & 25 & 20.83 & 88 & 73.3 & 2.65 \\
\hline Computer & 44 & 36.6 & 27 & 22.5 & 12 & 10.0 & 1.11 \\
\hline Video player & 34 & 28.3 & 22 & 18.3 & 14 & 11.67 & 1.0 \\
\hline Digital camera & 35 & 29.17 & 7 & 5.83 & 9 & 7.50 & 0.63 \\
\hline Flash drive & 31 & 25.5 & 12 & 10.0 & 8 & 6.67 & 0.65 \\
\hline Film projector & 45 & 37.50 & 3 & 2.50 & 2 & 1.67 & 0.47 \\
\hline
\end{tabular}

\section{Level of Usage of ICTs by Farmers in Benue State}

The result of the usage of ICTs by the respondents is presented in Table 2. On the overall, mobile phone was found to be the most used ICT tool $(\bar{x}=2.38)$. The level of usage of television was also highly rated $(\bar{x}=2.38)$.
The high rate of mobile phone usage could be because mobile phones are easily affordable and could be used by even illiterate farmers. Communicating marketing information through these channels would therefore increase the likelihood of farmers having using the information.

Table 3: Respondents' Level of usage of ICTs

\begin{tabular}{lcccc}
\hline ICTs & \multicolumn{3}{c}{ Level of Usage } \\
\cline { 2 - 5 } & High usage (\%) & Moderate usage (\%) & Low usage (\%) & Mean $(\bar{x})$ \\
\hline Television & 39.17 & 40.0 & 11.67 & 2.09 \\
Internet & 13.33 & 17.50 & 35.0 & 1.1 \\
Mobile phone & 59.17 & 28.3 & 4.17 & 2.38 \\
Computer & 8.3 & 16.6 & 40.8 & 0.99 \\
Video player & 5.0 & 17.5 & 34.1 & 0.84 \\
Digital camera & 4.17 & 6.6 & 30.8 & 0.56 \\
Flash drive & 5.83 & 9.17 & 27.5 & 0.63 \\
Film projector & 1.67 & 2.5 & 37.5 & 0.47 \\
\hline
\end{tabular}

\section{Effect of the Socio - economic Characteristics of Respondents on their Level of Usage of ICTs}

Binary logistic regression was used to test the effect of respondents' socio economic characteristics on their level of ICT usage, and the result is presented in Table 4. Out of the six explanatory variables in the model, only two were significant; the farming experience and farm size.

Farming experience had a negative coefficient (0.95 ) and was significant $(0.01)$ at a $1 \%$ level of probability. This means that the respondents with more farming experience are less likely to use ICTs. This could be because farmers with several years of experience may be used to their old ways of marketing their produce, and not readily use modern ICT facilities to improve their market access.
Farm size had a positive coefficient $(0.17)$ and significant $(0.04)$ at a $5 \%$ level of probability. This implies that the probability that the respondents with higher farm size leads to higher probability of using ICTs. Increased farm size leads to higher farm output which implies that ICTs will be needed to provide information on how to market this farm produce to avoid wastage.

The Pseudo $R^{2}$ for the regression is 0.4714 , indicating that the variables tested accounted for $47.1 \%$ of the variations in the dependent variable. The chisquare value of the model was 28.30 and was significant at a $1 \%$ level of probability. This implies that the respondents' socio economic characteristics affected their usage of ICTs. The null hypothesis for the study was therefore rejected. 
Table 4: Effects of Respondents' Socio - economic Characteristics on their Level of Access to ICTs

\begin{tabular}{lllll}
\hline Socioeconomic characteristics & B & SE & Wald & Sig. \\
\hline Age & -0.007 & 0.312 & -0.26 & 0.798 \\
Education & 0.317 & 0.480 & 0.66 & 0.510 \\
Farming experience & -0.950 & 0.384 & -2.47 & $0.013^{*}$ \\
Household size & 0.159 & 0.759 & 0.21 & 0.833 \\
Farm size & 0.172 & 0.086 & 1.99 & $0.047^{*}$ \\
Income & 0.392 & 7.708 & 0.51 & 0.611 \\
Constant & 1.095 & 1.089 & 0.01 & 0.315 \\
& \multicolumn{4}{l}{} \\
$\mathrm{X}^{2}=17.14$; Sig. = 0.0002; log likelihood ratio = - 68.424; Nagelkerke $\mathrm{R}^{2}=0.4714$ \\
${ }^{*}$ represent significance at 5\% level of probability
\end{tabular}

\section{CONCLUSION AND RECOMMENDATIONS}

The findings of this research reveal that most of the respondents were in their active ages of production, highly educated and have been farming for a relatively long period of time. The respondents had large household size, but had low income and small farms. The respondents had high accessibility to mobile phones and television, and these were the ICTs mostly used by the respondents. The farming experience and farm size of the respondents significantly affected their level of use of ICTs. The following recommendations were made based on these findings:

1. Marketing information should be communicated to the farmers through ICTs that they have high access to and use, which are mobile phones and television.

2. The farmers should be encouraged by extension agents to use the ICTs that are not highly used, especially the internet, while the government provides the infrastructure necessary for the use of the ICTs.

3. Farmers should be encouraged to increase the size of the farms they cultivate, as this would have a positive impact on their use of ICTs.

\section{REFERENCES}

Adegboye, R.O. (2004). Land Agricultural and Food Security in Nigeria, $3^{\text {rd }}$ faculty lectures, Faculty of Agriculture, Univsersity of Ilorin, 25/2/2004.P7.

Afolabi, J.A (2010). Analysis of loan repayment among small scale farmers in Oyo state, Nigeria. Journal of social sciences, 22(2); 115-119.

Ajayi, M. T. (2002). Sources of information of improved Technologies adopted by Farmers: A study of farmers in Akinyele Local Government of Oyo State, Nigeria. Journal of Extension Systems 18(2); 94103.

BNARDA (2005): Unpublished Annual Report on Agriculture. Vol. 1(1): 10-13

Food and Agriculture Organization (FAO) (2009). State of food insecurity in the world: Addressing food security in protracted crises. Rome: FAO

Hassan, M.A., Hassan, M.S., Shaffril, H.A.M. \& D' Silva, J.L. (2009). Problems and obstacles in using information and communication technology (ICT) among Malaysian Agro-Based Entrepreneurs. European Journal of Scientific Research, 36 (1); 93101.

Molony, T. (2008). Running out of credit: the limitations of mobile telephony in a Tanzanian agricultural marketing system. Journal of Modern African studies, 46(4); 637-658.

NPC (2006). Nigeria National Population Census Report

Okwu, J. O, Kuku., A.A and Aba, J. I. (2007). An assessment of use of Radio in Agricultural Dissemination: a case study of radio Benue in Nigeria. African Journal of Agricultural Research, 2(1); $014-018$.

Otene, V.A, Ezihe, J.A.C, Torgenga, F.S.(2017). Assessment of mobile phone usage among farmers in Keana local government area of Nassarawa State, Nigeria. Journal of Agricultural \& Food Information, DOI: 10.1080/10496505. 2017.1361829

Pade, C., Mallinson, B. \& Lannon, J. (2005). The use of ICT for rural development andpoverty alleviation in developing countries: An investigation of gender specificagricultural development: The South African Journal of Information andCommunication Issue. Retrieved from http:/www.link.wits.ac.zs/jrournal/jo6 - pade -pdf on April 11, 2013.

Cite this Article: OTENE VA, IJUH RH, IHEANAETU AC and CHIA JI (2018). Assessment of use of Information and Communication Technologies (ICTs) by Farmers in Makurdi Local Government of Benue State: Implications for Accessing Marketing Information. Greener Journal of Agricultural Sciences, 8(9): 251-256, http://doi.org/10.15580/GJAS.2018.9.091218135. 